\title{
The measurement of the economic, social and environmental impact of Peer to Peer online platforms: The case of collaborative consumption ${ }^{1}$ \\ La medición del impacto economic, social y medioambiental de las plataformas online entre iguales. El caso del consumo colaborativo $^{2}$
}

\author{
Ángel GoRdo López \\ Universidad Complutense de Madrid \\ ajgordol@ucm.es (ESPAÑA) \\ JAVIER DE RIVERA \\ Universidad Complutense de Madrid \\ jigro@ucm.es(ESPAÑA) \\ Paul R Cassidy \\ Universidad Complutense de Madrid \\ pcassidy@ucm.es (ESPAÑA)
}

Recibido: 30.102019

Aceptado: 21.10 .2020

\footnotetext{
${ }^{1}$ The research presented in this article is part of the project «El Triple Impacto del Consumo Colaborativo» as part of a reseach contract, artículo 83, with Ediciones OCU, S.A (ref 2-2015) (15th January-31st Agugust 2015). The research was part of a wider project on The triple impact of P2P collaborative consumption funded by four European consumer associations: Organización de Consumidores y Usuarios [OCU] (Spain), Test Achats / Test-Aankoop (Belgium), Altroconsumo (Italy), and Deco Proteste (Portugal).

2 We want to thank the representatives of the four consumer organisations that funded this research and in particular the Project Coordinator, Amaya Apesteguía (OCU), for their support and their invaluable insights and feedback. We further thank the two anonymous reviewers for their useful and thoughtful comments. All errors remain ours.
} 


\begin{abstract}
Over the last decade, the rise of peer-to-peer online markets has become a major sociocultural and economic phenomena and been described as a collaborative or sharing economy. However, understanding their impact has been mired in controversy and disagreement. Proponents of the sharing economy hail its potential to be a panacea for many of the world's problems, but more critical perspectives point to research that undermines these claims. The rapid growth of this type of activity has placed public administrators in particular under pressure to develop appropriate policy and regulation. However, policy development is severely hindered by a lack of data and suitable measurement techniques. Work to develop appropriate data measurement tends to focus on economic measurement at the expense of social and environmental impact. This research paper seeks to contribute to understanding this problem area by taking a comprehensive triple impact perspective (economic, social and environmental) of the object of study. Employing a Delphi technique, the research developed forty-seven impact indicators across the three areas of measurement.
\end{abstract}

\title{
KEY WORDS
}

Delphi study; digital technology; impact indicators; platform economy; sharing economy.

\section{RESUMEN}

A lo largo de la última década, el crecimiento de las plataformas de intercambio entre iguales, descritas como economía colaborativa, representó un de los fenónenos económicos y socio-culturales más importantes. Los defensores de la economía colaborativa resaltan su potencial para convertirse en la panacea de los grandes problemas mundiales, mientras que las perspectivas críticas apuntan a investigaciones que contradicen estas ideas. El rápido crecimiento de este tipo de actividad ha puesto a la administración pública bajo la presión de tener que desarrollar medidas de regulación adecuadas. Sin embargo, el desarrollo de regulación en este sentido adolece gravemente de la falta de datos y de técnicas adecuadas para medir el impacto. Los intentos por medir este impacto están por lo general concentrads en producir indicadores económicos, a expensas de la medición del impacto social y medioambiental. Esta investigación trata de contribuir a esta cuestión desde una perspectiva holística que estudia el triple impacto (económico, social y medioambiental) de este objeto de estudio. Recurriendo a un estudio Delphi esta investigación ha desarrollado 47 indicadores de impacto en estas tres aéreas de medición. 


\section{PALABRAS CLAVE}

Estudio Delphi; economía de plataformas; indicadores de impacto; sharing economy; tecnologías digitales.

\section{INTRODUCCIÓN}

Predicated on a change in consumption patterns towards one in which digital technologies create economies of scale that allow peers to take advantage of systematic overcapacity in consumer products (Gil, 2018; Benkler, 2004), the collaborative and sharing economy-more recently also referred to as the platform economy (Schmidt, 2017) or platform capitalism (Morozov, 2019; Srnicek, 2016; Vallas, 2019)—is undeniably one of the major socio-cultural and economic phenomena of the 21st century (Bulchand \& Melian, 2018; TNS, 2016; Huws \& Joyce, 2016). With industry revenues of nearly $€ 4.5 \mathrm{bn}$ and transaction turnover of €28bn in Europe alone (DeGroen, 2017), multi-billion dollar platforms, like Airbnb and Uber, have dominated the news (Hook, 2017; MartínezDíez, 2019), while many other not-for-profit platforms operate for altruistic and community-based reasons, mostly at the local level.

While there is little debate that economic recession, environmental meltdown, and social inequality are related to the emergence of the sharing economy, there is no agreement about its impact on society and how it should be addressed by public policy (Riso, 2020). Debate on the sharing economy has focused on its social, economic and environmental implications (de Rivera \& Gordo, in-print; Pargman, Erikson \& Friday, 2016; Martin, 2016). Platforms and other proponents advocate for it as a paradigmatic shift to sustainable economies and societies, where citizens are empowered, society is fairer, resources are consumed more efficiently, markets are dynamic and people save money (Botsman \& Rogers, 2010; Stokes et al., 2014; OuiShare, 2015).

However, an OECD (2016) report highlighted the many downsides to the contingent type work available in collaborative consumption (Rogers, 2016). Findings by Demary (2015) and Schor et al. (2016) contradict the supposed social benefits of connectedness and fairness of both for-profit and not-for-profit organizations. Similarly, criticisms have been raised regarding the supposed emergence of environmentally sustainable consumption practices (Demailly \& Novel, 2014; Frenken \& Schor, 2019; Dreyer et al 2017; Murillo, Buckland \& Val, 2017).

Throughout these debates, public administrators, market regulators, lawmakers and consumer organizations have been left scrambling to provide adequate policy responses to resolve the on-going conflict and the new challenges of supporting enterprise while protecting consumers and workers (FernándezTrujillo, 2020; Rani \& Furrer, 2019). In addition, recent studies have shown the complexity of measuring the impact of specific platforms, such as Airbnb and Uber, on their competititors in the traditional economy (Dogru et al., 2020; 
Skok \& Baker, 2019). Most notable, however, is that the majority of the efforts to measure the sharing economy and its impacts conducted to date have focused almost exclusively on economics and the labour force (Fernández-Macías, 2017; Riso, 2020), while social and environmental issues, two important dimensions of the collaborative economy proposition, have been largely ignored (Parguel, Lunardo \& Benoit-Moreau, 2017; Schor, 2014).

In this context, national consumer organisations from four European countries - Organización de Consumidores y Usuarios [OCU] (Spain), Test Achats / Test Ankoop (Belgium), Altroconsumo (Italy) and Deco Proteste (Portugal) - commissioned an ambitious research project whose overall aim was to account for the impact of collaborative consumption platforms in society. This study was published under the title «Collaboration or Business? Collaborative Consumption: From Value to Users to Society with Values» (OCU, 2016). The research presented here was a central part of this project. Its aim was to identify appropriate social, economic and environmental indicators to measure the impact of online peer-to-peer collaborative consumption platforms. To do this, we employed a three-round Delphi technique with thirty-two experts and stakeholders. Despite the five years that have passed since we started the fieldwork, to date, this is still one of the few studies that provides independent and rigorous analysis of the impacts of peer-to-peer exchange platforms on society.

\section{CONCEPTUAL OVERVIEW}

The sharing economy has been promoted as an innovative and disruptive economic model and "a major commercial opportunity for entrepreneurs, companies, industries and/or countries" (Martin, 2016: 153). This growing phenomenon around the world brings with it an economic model characterized by reallocating the idle capacity of goods and services, such as car seats or living spaces, through secondary markets and sharing using web-based information and communication technologies (Benkler, 2004; Mair \& Reischauer, 2016). A particularly prominent and controversial subset of the sharing economy consists of "collaborative consumption" (CC) business models, which, as Dreyer et al. (2017: 87) note, "emphasize the commercial aspects of sharing" and involve coordinating "the acquisition and distribution of a resource for a fee or other compensation" (Belk, 2014: 1597).

There is significant ambivalence surrounding the turn to a sharing economic model (Acquier et al., 2017; Martin, 2016). Authors such as Allen and Berg (2014) argue that collaborative consumption represents a necessary adjustment to over regulated and over protected markets, and Coyle states that the result is "pure gain in economic efficiency benefiting both sides" (2016: 8). The evidence seems clear that it has stimulated competition and had a deflationary effect on prices in sectors such as accommodation and transport (Laurell \& Sandström, 2017; Zervas, Proserpio \& Byers, 2017). But, is such competition 
fair and to what degree does it depend on informal labour relations, lack of regulation and tax avoidance?

The arguments against platform labour focus on flexibilisation, whereby economic risk and liability are unequally shared, while "control criteria" are still applied to working conditions (OECD, 2016; Eglash, 2016; Rogers, 2016). Platforms are viewed as contributing to employment precariousness by privatising risk, which leaves prosumers, or providers, with little protection in terms of health and social security (Fernández-Trujillo, 2020; OECD, 2016). These downsides of the sharing economy in the labour market have been confirmed by various reports from the European Commission (2016; 2017), the European Parliament (2017) and more recently by the International Labour Organisation (ILO, 2018). Given that most platform workers do not earn all or most of their income online (DeGroen \& Maselli, 2016), that they generally participate reluctantly and for short periods of time, the use of terms like 'entrepreneur' to describe them is misleading, particularly as they do not receive the typical financial benefits of entrepreneurship as a trade off for a loss of social security (Rani \& Furrer, 2019). Finally, although platforms claim to be about individual prosumers, research on Airbnb, for example, shows that many corporations also operate on the platform (Cox \& Slee, 2016).

The sharing economy is considered to blur the boundaries between production and consumption, the social and the economic. Meeting new persons, authenticity and developing new friendships are some of the outcomes of peer to peer exchanges between strangers (Belk, 2014). Platforms discursively frame their activities within these narratives of sharing, collaboration and connection (Wagner et al., 2015), presented as ideological counter offerings to the isolation and separation of traditional marketplaces (Richardson, 2015). Furthermore, technologically driven reputation systems have been touted as meritocratic social assets (social currency) that make self-regulation possible through crowd-sourced information on provider and consumer performance by reducing information asymmetry (Arroyo, Murillo \& Val, 2017). In this sense, the way trust is gained and managed in the collaborative economy is identified by its advocates as a key advantage of the model (Botsman, 2017).

Other studies have found that technology may actually impede or weaken social relationships in collaborative consumption contexts (Schor, 2104; Parigi $\&$ State, 2014). While some authors have focused on the way the sharing economy may prompt the monetization of social relations or social capital (Teubner, Hawlitschek \& Dan, 2017). Additionally, Edelman and Luca (2014) found that race based discrimination is reproduced. The work by Schor et al. (2016) on notfor-profit exchange and digital platforms, shows how participants use cultural capital to "establish superior position in the context of various types of exchanges" (p. 66) Furthermore, evidence suggests that the self-regulatory function of reputation and rating systems are not reliable and easily manipulated (Codagnone, Biagi \& Adabie, 2016).

Turning to the environmental impacts of the sharing economy, promoters champion its capacity to be a driver of a sustainable economic system with a re- 
duced carbon footprint (Botsman \& Rogers, 2010; Torregrossa, 2013; Heinrichs, 2013). However, Schor (2014) argues that these claims have become truisms, based more on assumptions than hard evidence, while "the actual environmental impacts of the sites are far more complicated". In this respect, Frenken \& Schor (2019) make a good point both in terms of the lack of data and the complexity of the issue, while also pointing out the importance of distinguishing between different kind of practices that have been wrongly defined as part of the "sharing economy", in order to account for their environmental impact.

In terms of the complicated nature of measuring the environmental impact, it is overly simplistic to assume that the sharing economy is a type of voluntary correction to a socio-economic model that is living beyond its means (Pargman et al., 2016). It is necessary to consider a whole series of first and second order effects on a holistic basis (Börjesson-Rivera et al., 2014). Cohen (2016) draws attention to the prevalence of the Jevons Paradox, which refers to how technological developments resulting in increased efficiency can perversely drive up consumption. In the sharing economy, a number of studies have demonstrated this 'rebound' effect, which drives up consumption and reduces sustainability in accommodation and transport (Schröder et al., 2019; Verboven \& Vanherck, 2016, Frenken, 2017). Pargman et al. (2016) conclude that it will only be environmentally sustainable when a limits based approach is taken that restricts overall structural unsustainability, or what Cohen (2016) refers to as sufficiency instead of efficiency. Finally, it is also necessary to consider the wide range of sectors of activity in which collaborative consumption operates, as we have discussed elsewhere (Gordo, de Rivera \& Cassidy, 2015; de Rivera, 2019).

Thus, there is significant uncertainty surrounding the value impacts of collaborative consumption as one of the most important subsets of the sharing economy and, in more general terms, the online platform economy. However, to understand the impacts of collaborative consumption requires constructing a framework based on objective and measurable indicators. The following section describes the research methodology we used to such an end.

\section{METHODOLOGY}

The main objective of the independent international research framework this paper draws on was the development of indicators to assess collaborative consumption platforms in terms of their economic, social and environmental impacts. As we have noted above, collaborative consumption has been fuelled by its association with economic benefits for both consumers and providers. In addition, the sharing economy has been associated with the idea of fostering a more circular and sustainable economic model as mentioned earlier. Finally, it is also claimed to provide social benefits, in the sense of facilitating more meaningful contacts (bonding) and increased social mixing (bridging) (Dillahunt \& Malone, 2015). 
After an extensive literature review of previously published documentation to identify the main debates on the issue, the Delphi research described here was aimed at identifying measurable dimensions and concrete impact indicators to evaluate the impact of collaborative consumption. These indicators were then used to develop an evaluation tool to measure the economic, social and environmental impact of peer-to-peer collaborative consumption platforms: The Triple Impact Assessment Questionnaire. In this research strategy, other methodologies were also applied, such as netnographic research aimed at examining the complexities of platforms' social impacts (de Rivera et al, 2016).

The Delphi study was a crucial phase of the overall research because it was used to conceptualize the issue, while avoiding oversimplification and baseless assumptions. This methodology, based on systematically consulting groups of experts through a questionnaire, has long been applied to address complex issues (Linstone \& Turoff, 2002). Therefore, its use was highly indicated to address the study of an object as broad and wide-ranging as the impact of the collaborative economy, where knowledge has not yet been formalised into accepted arguments and structures.

An effective Delphi study requires qualified experts who have an in-depth understanding of the subject (Rowe \& Wright, 2001). Following Okoli \& Pawlowski's (2004) approach for expert selection, and with the aid of previous documentary analysis, we identified a list of international experts (or stakeholders), grouped by their expertise and background in economic, social and environmental issues related to the collaborative economy. This grouping rationale and the multi-panel design of the Delphy study was based on developing precise measurement indicators for each of the areas of impact, as required by the demand context.

We invited ninety-eight experts to participate, of whom thirty-two accepted. The expert panel was made up of representatives of CC platforms (11-34.4\%), followed by consultants/think-tank members $(9-28 \%)$, public administrators $(4-12 \%), \mathrm{CC}$ researchers $(4-13 \%)$ and consumer organization $\mathrm{CC}$ experts $(3-9 \%)$. Regarding geographic distribution, the experts were drawn from eight countries, with a noticeable bias toward Spain (16-50.0\%). In terms of distribution by expertise, the experts were directly asked to state their area of expertise in order to confirm our previous grouping: thirteen identified themselves as economic experts, twelve as social experts and six as experts in the environmental dimension of CC.

Table 1. Response rates. Source: By authors

$\begin{array}{lccccc} & \begin{array}{c}\text { No of } \\ \text { Experts }\end{array} & \begin{array}{c}\text { Response } \\ \text { rate }\end{array} & \begin{array}{c}\text { Economic } \\ \text { Experts }\end{array} & \begin{array}{c}\text { Environmental } \\ \text { Experts }\end{array} & \begin{array}{c}\text { Social } \\ \text { Experts }\end{array} \\ \text { Round } 1 & 32 & & 13 & 6 & 12 \\ \text { Round } 2 & 29 & 90.6 \% & 13 & 6 & 10\end{array}$




\section{Round 3}

The success of a Delphi process depends on the commitment and continued participation of experts until the process is completed, and can be susceptible to significant attrition after the first round (Linstone \& Turrof, 2002; Keeney, Hasson \& Mckenna, 2011). In this study, we employed three iterations or rounds, which were preceded by a pilot testing phase with an Advisory Group ${ }^{3}$. The fieldwork took place between February 2015 and May 2015. Table 1 outlines the round by round response rates for this study, which at $90.6 \%$ for Round 2 and $78.1 \%$ for Round 3 are acceptable when compared to other studies (Keeney, Hasson \& Mckenna, 2006). However, the reduced number of experts in the environmental panel was obviously a methodological limitation we had to face, as will be discussed later.

Prior to the implementation of the first round, an online questionnaire was developed and piloted with the Advisory Group and changes were made based on their feedback. The questionnaire for the first round began with three openended questions; all panellists were asked to propose several economic, social and environmental impact indicators, along with their reasoning. Subsequently, they were presented with approximately twenty indicators for each dimension and asked to choose ten and rank them on the basis of their relevance and measurability. This "seed-list" of indicators (Schmidt et al., 2001) was developed based on the results of desk research and reviewed by the Advisory Group.

Following data collection, open-ended responses were analysed through a process of progressive categorization and coding until theme areas emerged, while the closed-end ranking of the seed-list items was statistically analysed. The final output was a consolidated list of items, including improved items from the closed-end analysis and new items from the open-ended analysis. In the second round, experts were asked to identify and rank the seven items they thought were most important in the consolidated list of indicators. Through this ranking process, key indicators were identified and experts had the opportunity to comment on their rankings or individual indicators.

Based on the main ideas and feedback from rounds 1 and 2, the researchers worked to develop more "measurable" indicators for round 3. In the final round, the experts were divided into three panels, according to their own area of expertise (economic, environmental or social), each receiving a questionnaire with a different list of indicators. In each panel, the questionnaires included the results from Round 2, including the overall score (from all panellists) and the scores from the group of experts in their own field of expertise. Then, the experts had

${ }^{3}$ Made up of the coordinator, members of the four consumer associations and collaborative economy think-tank experts (Ouishare) and a researcher from ICADE University, Madrid 
to rate the importance of each item on a 5-point Likert scale (from not at all important to very important).

Finally, we have to point out that the broad scope of the research suffers certain methodological limitations to be addressed in further research. First, the expert/stakeholder group has a significant bias toward Spain $(50 \%)$ and Europe $(87.5 \%)$. Second, given the exploratory nature of this research, the indicators produced were not always realistic in terms of measurability, as we found out later in the platform survey we conducted as part of the broader research program, in which most platforms offered considerable resistance to divulging certain information, even on a confidential basis (OCU, 2016). Third, the multi-panel strategy implied a reduced $n$ in round 3, especially on the environmental panel. For the development of rounds 1 and 2, this had little impact as all experts participated; however, as the third multi-panel round was only completed by four of the six environmental experts, it presents some difficulties in the ratings of the indicators, and this caused problems with absolute response numbers in the last round. Nevertheless, we think that the responses from previous rounds provide enough valuable data to justify the presentation of the results. Alternative research designs may be used to model the environmental impact dimension in more detail, and should include a sufficient number of experts.

\section{RESULTS}

The results of the final round (tables 2, 3 and 4) are presented separately for each of the three impact areas (social, economic and environmental). There are a total of 47 indicators organized in nine sub-dimensions (three in each main impact area). These items were developed from the results of the second round, and were rephrased in order to generate a list of items that could be measured. The Round 3 results are ordered according to the mean importance (rated on a 5-point Likert scale) awarded by the experts. Indicators that scored below 3.00 were eliminated --only two in the social dimension and one in the environmental dimension. In the case of two or more indicators receiving the same importance score, we used the standard deviation (SD) as a secondary measure of rank. The interpretation of the results are illustrated with quotations from the experts' comments in the Round 1 open-ended section.

\subsection{Economic impact indicators}

The list presented below is based on the analysis of expert panellists in their own field (in this case the economic impact of the sharing economy) in the third and final round. It consists of thirteen indicators (table 2) organized into three sub-dimensions: a) prosumer empowerment, b) consumer empowerment, and c) 
macro level economic stimulation. The economic impact indicators are identified as $\mathrm{EC} 1, \mathrm{EC} 2$, etc.

The prosumer empowerment sub-dimension looks at how collaborative consumption empowers 'new' economic actors, as prosumers, to generate wealth by taking advantage of idle resources of goods, services and people. Its importance is evident in the fact that three of the top five indicators are related to this sub-dimension. The key role of the monetization of idle capacity (indicator EC4, ranked $2^{\text {nd }}$ ) for this sub-dimension is illustrated by Expert 13 when noting that peer-to-peer marketplaces offer many opportunities for generating additional income from idle assets, for instance by renting out a room, an apartment, a car, or by delivering services via task sharing platforms. Similarly, EC6 measures "the average amount of money earned per user on the platform", rated as 'important or very important' by 58.4\% of experts. However, the fact that the remaining experts scored this indicator between 2 and 3 may reflect some scepticism about income as a measure of impact. As Expert 1 states: they [prosumers] can easily see monetary revenue (if there is any) but it is interesting to compare this revenue with the different costs (e.g. labour, inputs, health). Expert 20 also relates this issue to labour precariousness, asking if gains are made or if secure labour is being substituted with poorer paid, unskilled low-quality labour at lower cost?

The consumer empowerment sub-dimension refers to consumption advantages accrued in terms of pricing, choice and access. Only one 'consumer empowerment' indicator was ranked in the top half of the list. However, this indicator (EC2, ranked 1st), defined here as "average savings to users by participating in CC" was ranked highest of all and relates to one of the predominant themes of CC. This would appear to relate to the utilitarian motives behind many users engagement in CC (to increase purchasing power). As Expert 13 states, most peer-to-peer marketplaces enable their users to save money on goods and services they usually spend their household income on, for example, by renting a car when needed rather than owning one. However, it is notable that $25 \%$ of the experts rated this indicator as 2 or 3 out of 5, indicating some level of disagreement, which, as Expert 1 says, may relate to the real cost of [...] consumption (e.g. time to search for information, compare providers and access the product). The three remaining consumer empowerment indicators (EC7, EC8, EC9) received scores predominantly in the range of 3 to 4 , giving them a low-to-middle rank in the list.

The economic stimulation sub-dimension examines impact on the local economy and total spending. It contains three indicators rated as having high, middle and low importance. The impact of $\mathrm{CC}$ on the local economy indicator $\left(\mathrm{EC} 1\right.$, ranked $\left.3^{\text {rd }}\right)$, with $66.6 \%$ of experts rating it as 'important or very important' to measure "the average revenue made by users, from the same location/ city/region". Linked to prosumer empowerment and employment, Expert 5 stated that it is very important to evaluate how [prosumers'] income contributes 
to the stimulation of local business and local products and services [...]. In this respect, there is some concern about the dynamics of the $\mathrm{CC}$ marketplace having a negative impact on local economies. As Expert 6 asked: Who wins? Platforms could shift profits from local to global market players [...] Money (and tax revenue) could move from the local market to global platforms. Instead of being more resilient on a local level, sharing could make you lose all autonomy. For its part the "average amount of money spent per consumer on the platform" (EC5, ranked 6th) was rated negatively by two experts. Finally, the "platform contribution to taxes" in the country of operation (EC13, ranked 13th) was the lowest rated indicator. 


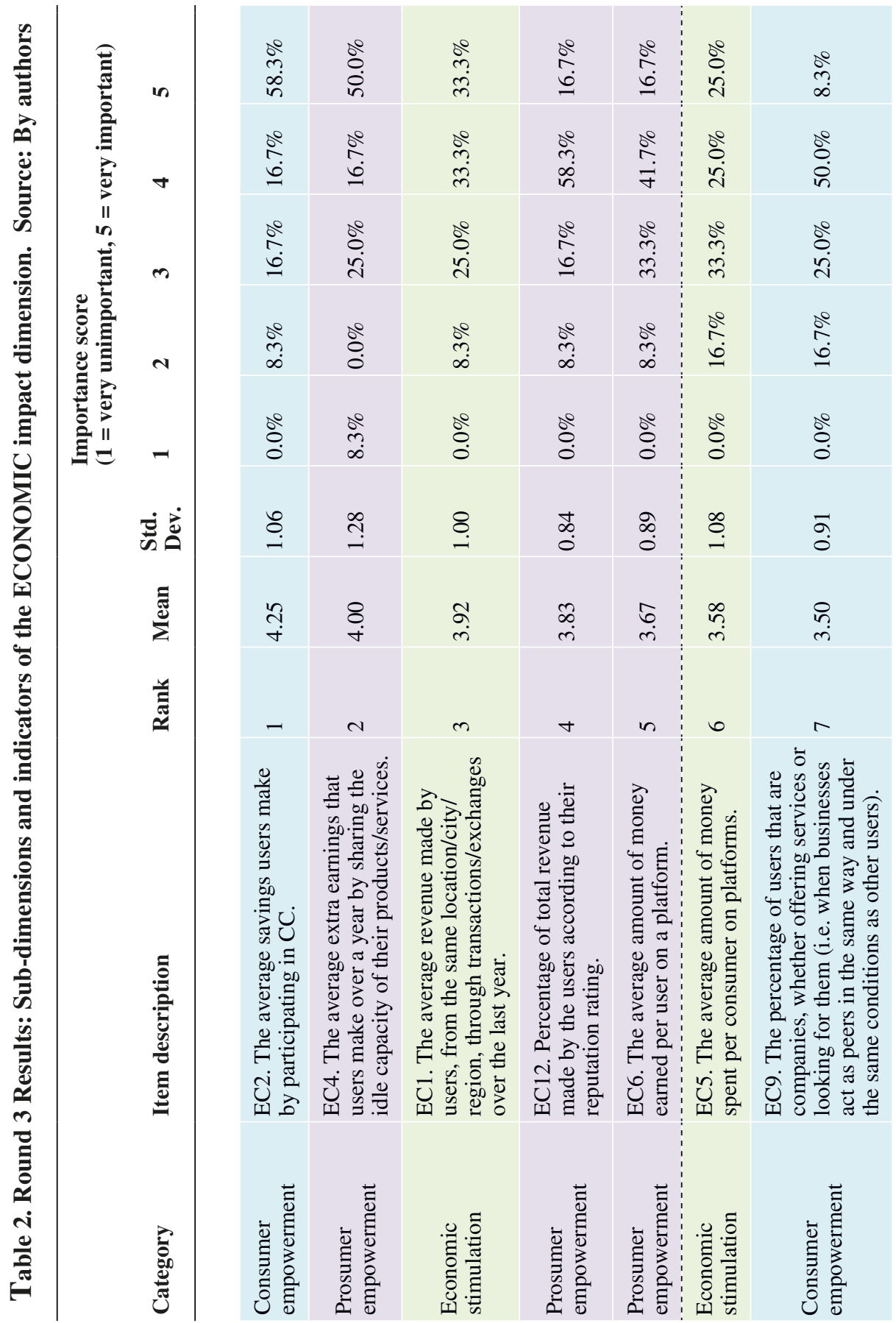




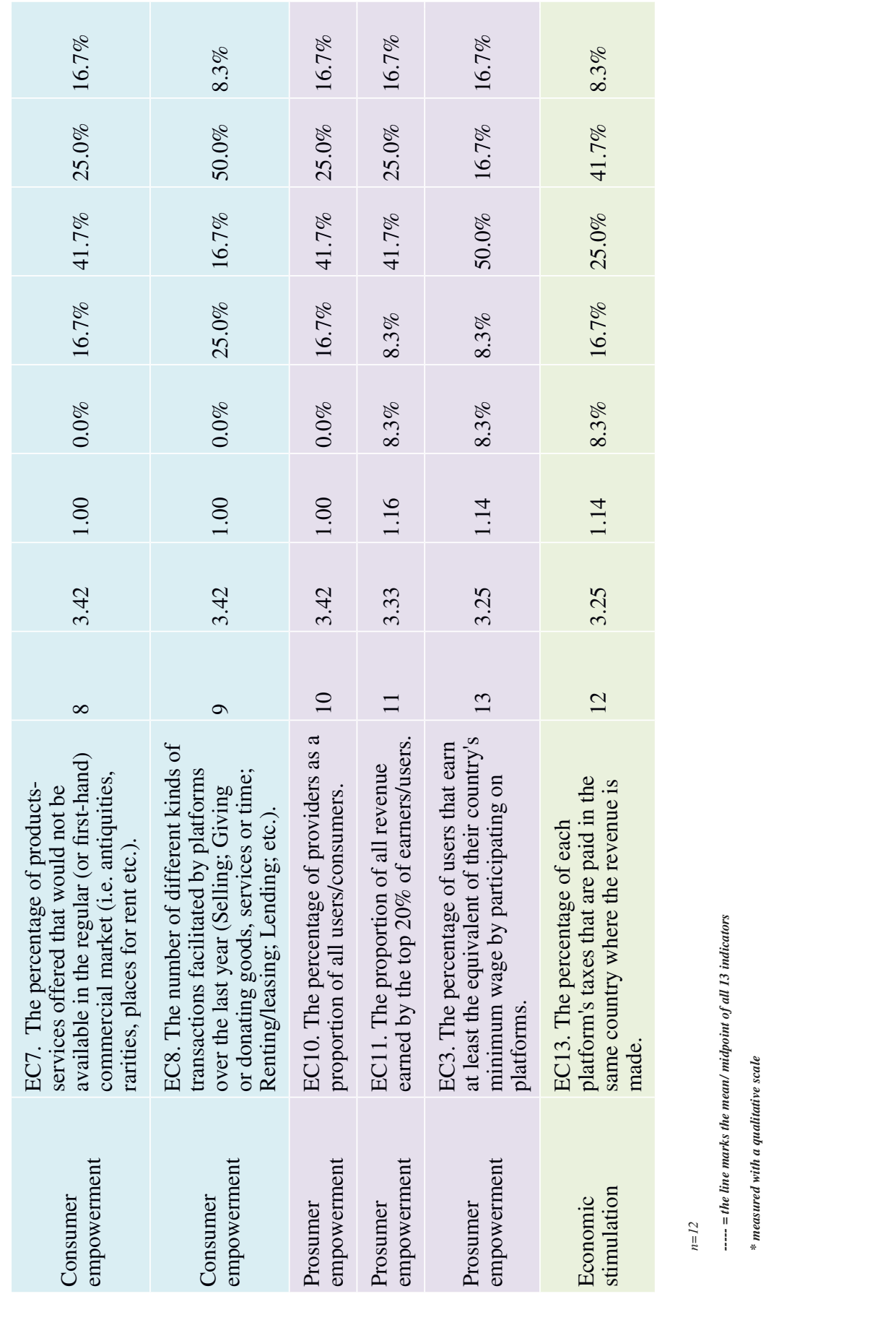




\subsection{Social impact indicators}

The 21 indicators in this impact area are organised into community building/ networking, social equality/bridging connections, and user empowerment subdimensions, the latter including trust and reputation aspects and monitoring and control indicators. It is notable that the community/network building indicators dominate the ranking, followed by social equality/bridging connections and trust/reputation aspects of user empowerment. Monitoring and control indicators all ranked below the average indicator score (mean of 3.70). The full Round 3 results for the social dimension are displayed in table 3.

The community/network building sub-dimension refers to the degree and quality of interaction between users. It ranked on average highest within the social impact area. The indicator focused on how CC platforms build local interactions is the highest ranked indicator (S10). Closely related is the indicator which seeks to measure whether CC platforms result in offline social gatherings (S4, ranked 2nd). This capacity to 'virtually' stimulate local offline connections considers how [CC] favours community relations and citizen collaboration: people help each other; first they form virtual communities that can then also be extended to off line contexts [Expert 29]. The capacity for creating connections in general is one of the fundamental purposes behind CC, because, as Expert 15 states, people who would have never met, meet with the sharing economy. However, Expert 26 questions this assumption by asking, how many of these interactions are [...] repeated? In this sense, while pure one-off transactions might be relevant from an economic perspective it does not find consonance as a social indicator. Consequently, the indicator which measures users' participation levels in terms of "average number of transactions per year" (S1, ranked 4th) is designed to measure how much involvement a user has in an online community, as opposed to engaging in one-off transactions. Similarly, the indicator S5 (ranked 5 th) focuses on user involvement in forums, community spaces and online groups. "The \% of non-monetized transactions (including alternative currencies), such as: swapping, gifting, bartering, etc." (S11, in $1^{\text {st }}$ position along with local interaction - S10) and "The \% of total transactions based exclusively on alternative currencies, including time as a currency in time-banks" (S12, ranked 6th), are viewed as very important indicators.

The bridging connections/social equality sub-dimension expands on community building/connections by looking specifically at interactions between users from different socio-cultural and economic backgrounds. Two of the three bridging connection indicators, "The proportion of all interactions between users with different education levels" (S7) (a proxy for social class) and "The proportion of all interactions between users of different age groups" (S8) (a way of measuring age based digital exclusion) were jointly ranked seventh above both user empowerment and monitoring and control categories, and are considered to be at least 'somewhat important' by all experts. However, S6, which measures cross national interactions, was ranked at the bottom of the list, and on reflection 
might be adapted to look more specifically at inter-ethnic or inter-cultural interactions.

The social sub-dimension trust and reputation indicators were midranked. They focus on the systems or technological tools that CC platforms make available to users to facilitate the development of virtual 'trust' or 'reputation'. In this respect, it is relevant to ask: do platforms and activities increase participants' trust and confidence in other participants, and people more generally? [Expert 18]. The three highest ranked indicators focus on sophistication of user profile technology (S20, ranked $7^{\text {th }}$ ), the possibility of uploading videos and other forms of expression (S21, ranked $10^{\text {th }}$ ) and the complexity of crowd sourced rating systems (S22, ranked 10th). The features that enable users to identify products/services they are looking for was considered less important $\left(\mathrm{S} 19\right.$, ranked $\left.12^{\text {th }}\right)$. Interestingly, the sophistication of virtual reputation systems (S23) was only ranked $16^{\text {th }}$, with a majority of the experts (55.6\%) only rating it as 'somewhat important', suggesting, perhaps, that the experts were not entirely sure of its value or how it may work.

The social monitoring and control sub-dimension indicators evaluate the development of systems to create a safe environment for users. At a general level it is noteworthy that these measures are all ranked below the mean for the indicators as a whole (average mean 3.70). This indicates some level of disagreement about these indicators' importance, though the fact that they all scored above 3.30 means that a small majority of experts rated the indicators as 'important' or 'very important'. Whether or not platforms have procedures against abuse, fraud or impersonation (S17, ranked $14^{\text {th }}$ ) was the highest ranked monitoring indicator. Related, S15 (ranked $18^{\text {th }}$ ) seeks to measure the proportion of users "reported for abuse, fraud or impersonation". The two other indicators focus on blocking and reporting systems: S18 (ranked $15^{\text {th }}$ ) aims to establish the ratio of misuse, while S17 (ranked 14th) acts as an overall measure of a platform's procedures against misuse. 


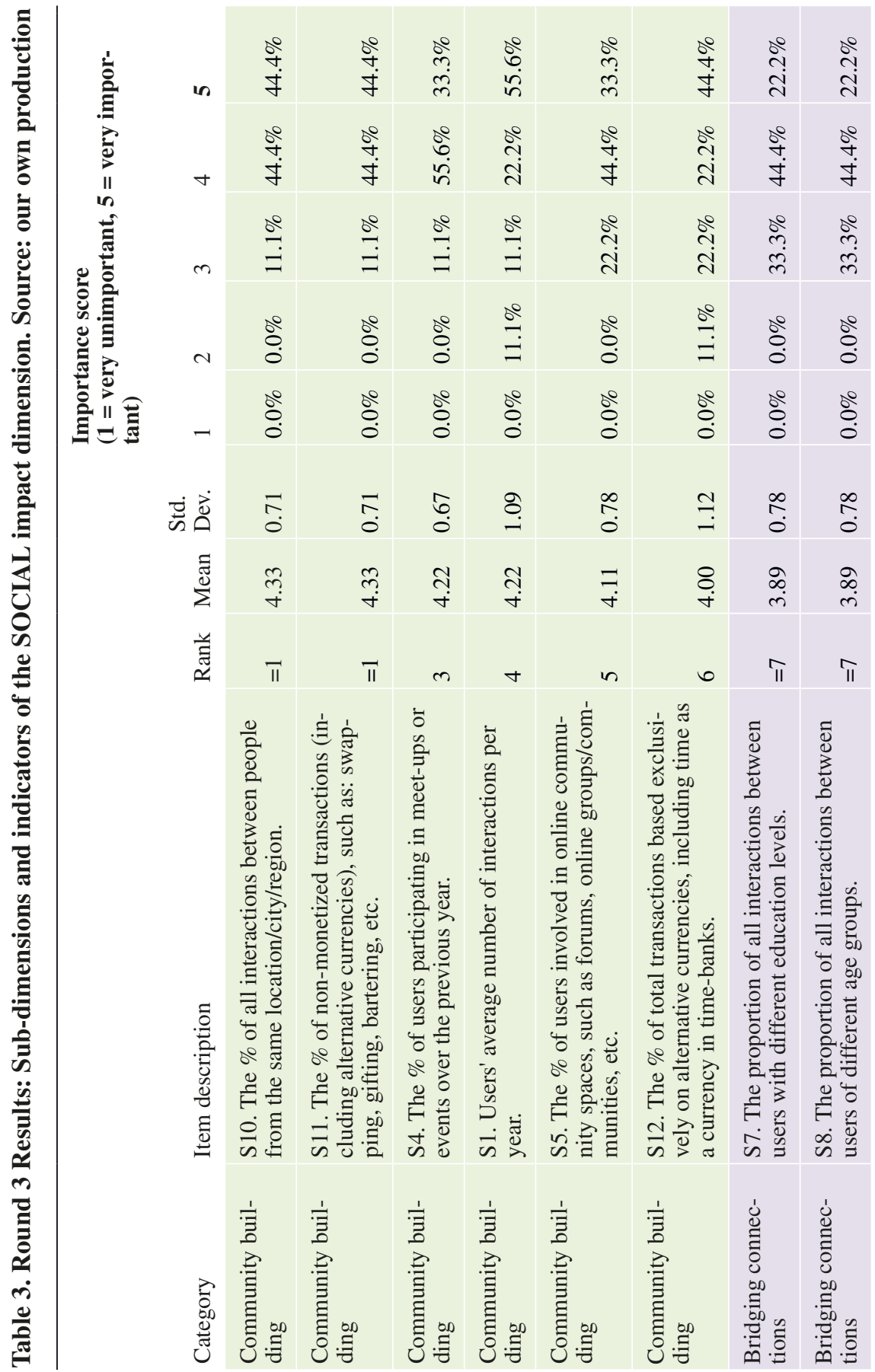




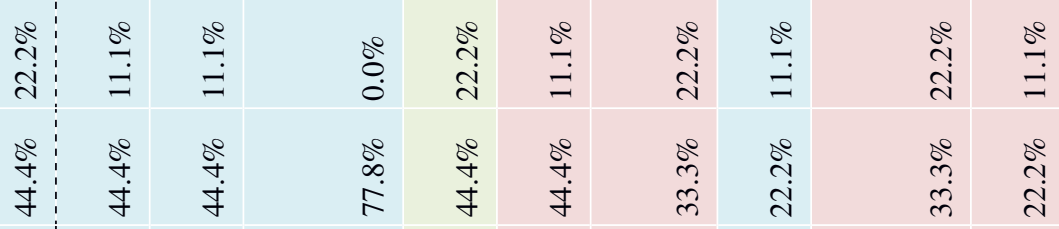

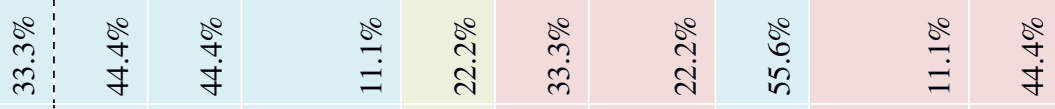

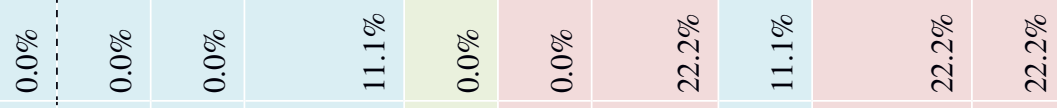

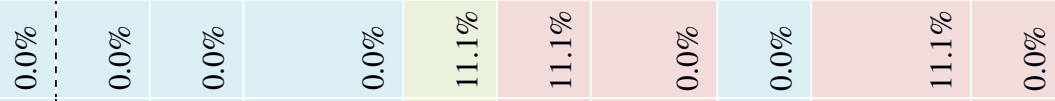

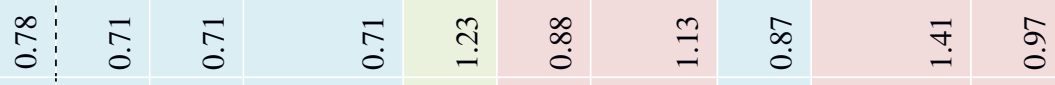

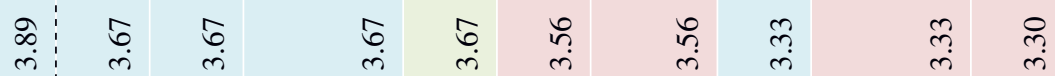

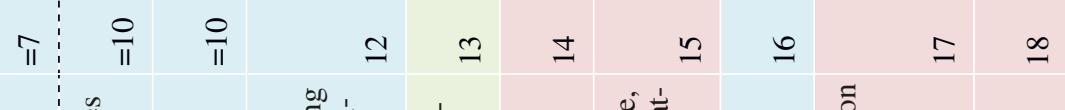

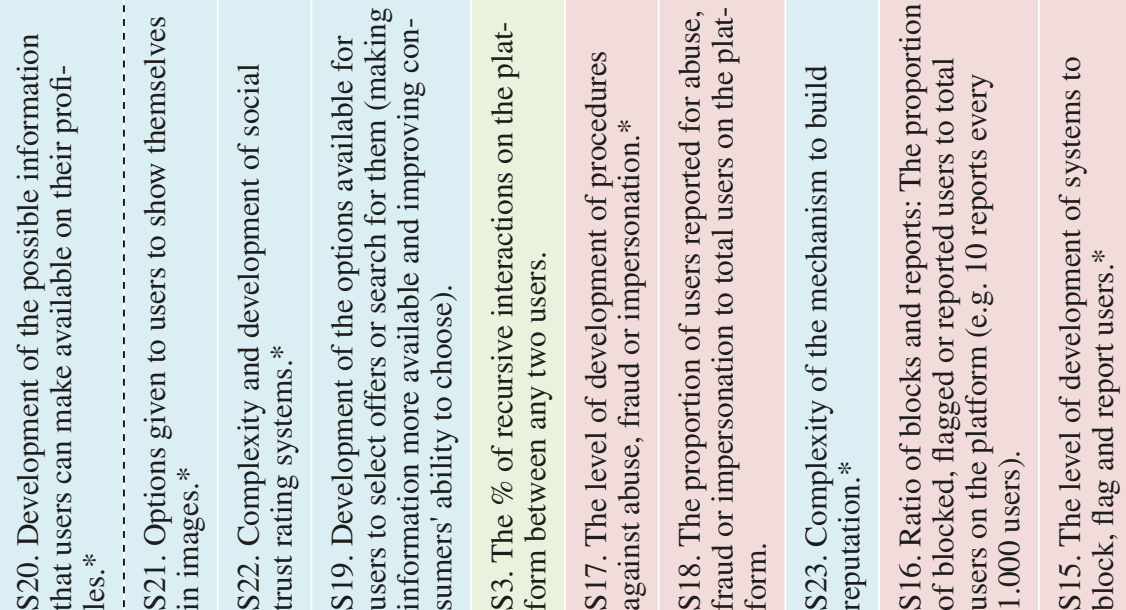

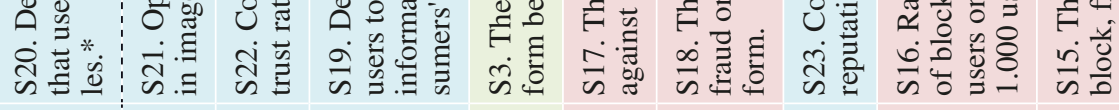

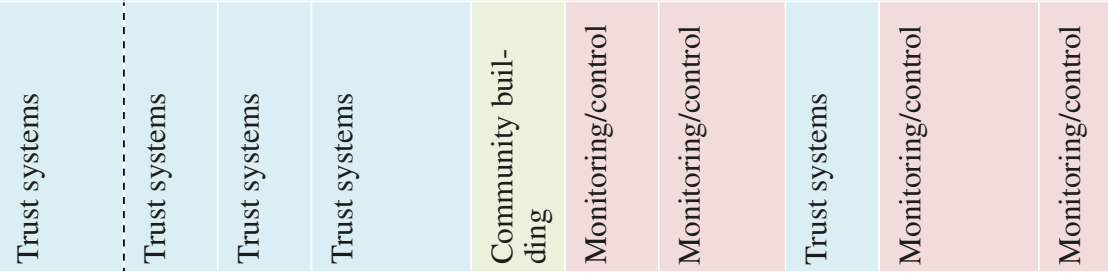




\subsection{Environmental impact indicators}

Eighteen indicators were inputted to the Round 1 environmental indicator list, of which twelve were retained, adapted or consolidated, six were dropped and four new items were developed for Round 2. The open-ended questions in the environmental section were particularly revealing. A number of experts expressed the view that $[C C]$ contributes to the fight against climate change [...] that our ecological footprint is surpassing what the planet can withstand, and we have to live with less. CC makes it possible to [...] avoid overconsumption [Expert 29]. In contrast, a significant proportion of the experts highlighted the potentially destructive contribution of $\mathrm{CC}$ through, for instance, 'the rebound effect', meaning that it is only possible to determine the environmental impact if saved resources are offset against re-spent resources [Expert 7]. The full Round 3 results for the environmental dimension are displayed in table 4 .

Items in the sustainable consumption category received, on average, the highest ranking across all three rounds and focus specifically on behavioural changes to consumption patterns. This indicates that the experts view CC's capacity to permit or facilitate consumers behavioural change as the most significant impact in this dimension. The top ranked item, which deals with "waste reduction due to sharing activities" (EV12, ranked 1st), typifies the view that $P 2 P$ communities make [better] use of existing products; there is less waste in the environment and a better use of resources [Expert 13]. Closely related, the item that seeks to measure "the percentage of platform transactions/services that involved products that can be used" (EV1) was ranked $3^{\text {rd }}$. Somewhat similarly the promotion of product durability (EV14, ranked 5th) is another key idea that emerged in the open-ended questions related to how CC "increased quality, repairability, shareability and the longevity of products".

\section{Sustainable production sub-dimension}

This sub-dimension examines sustainable supply chains and localisation. In the final round, seven sustainable production items were provided to the experts. Of these, two were ranked in the top five and two in the bottom three. The geographic sustainability indicator (EV10, ranked 1st) was the highest ranked. It measures the capacity to redirect production to the local level. In particular, it looks at how CC can favour local production and hence local consumption [leading to more] sustainable models [Expert 7]. Closely related, EV8 (ranked 4th) and EV9 (ranked $7^{\text {th }}$ ) consider the need to evaluate the "transportation efficiency" provided by $\mathrm{CC}$ in order to measure if it leads to a net reduction in the environmental footprint [Expert 22]. Two other indicators that consider disintermediation (EV11, ranked 5th) and hazardous waste reduction brought about through CC (EV13, 8th) receive high ratings.

\section{Awareness and culture change sub-dimension}

At an overall level the number of indicators in this category was reduced from six in Round 1 to two in Round 3, marking a notable downgrading as the 
scoring progressed. This appears to be because macro type indicators gave way to more specific measurements and because there was an increased focus on the sustainable consumption sub-dimension. This is exemplified by the ranking of the Round 2 item "Encourages users to change their lifestyles" (EV3) in second place overall, to its ranking in more measurable terms in thirteenth place in Round 3, where it was defined as "the percentage of users participating in environmentally friendly programs" (EV4). The other awareness/culture change item focused on how platforms maintain or develop "sustainable codes and practices promoted by the platform" (EV3), and was ranked 9th by the experts. 


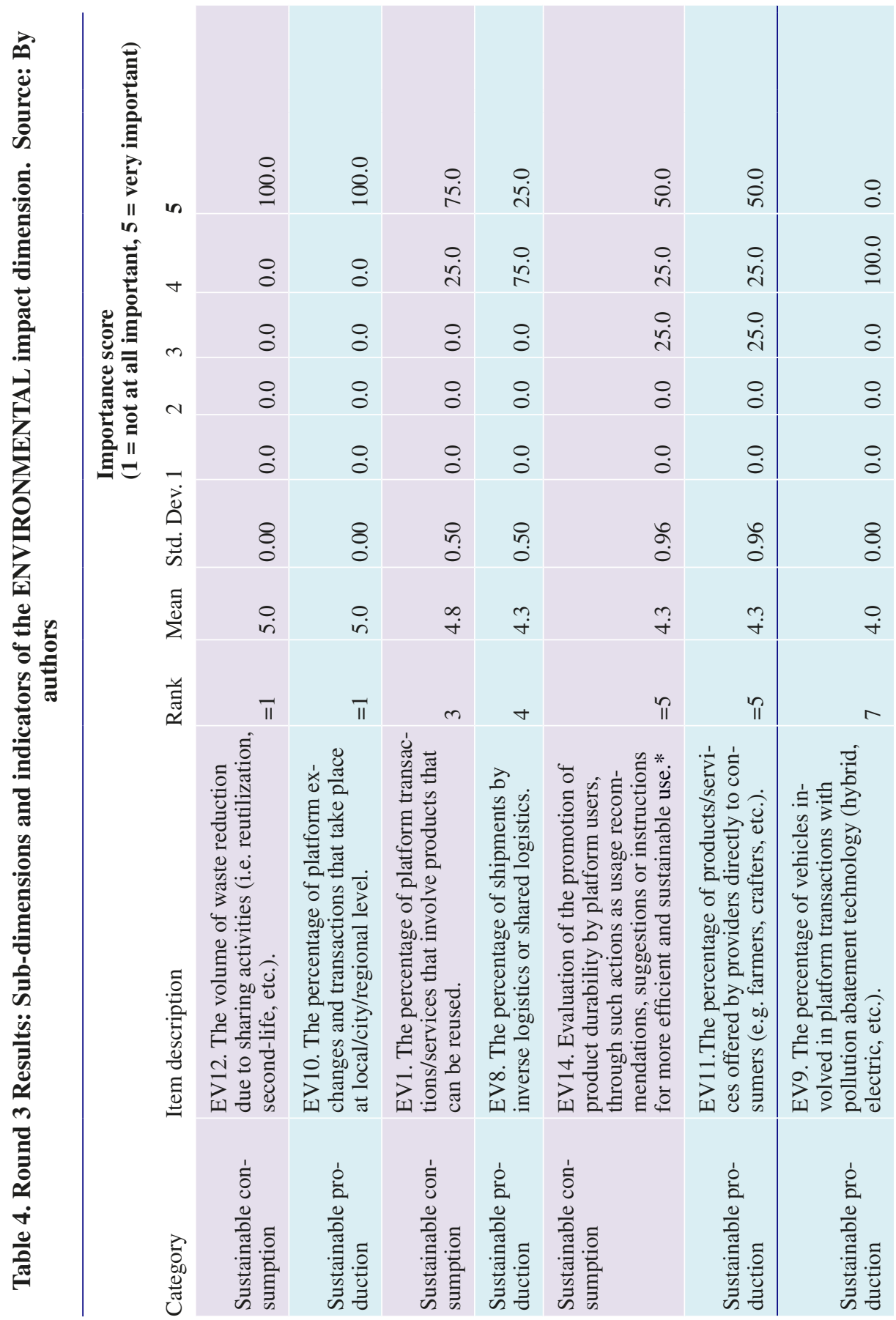




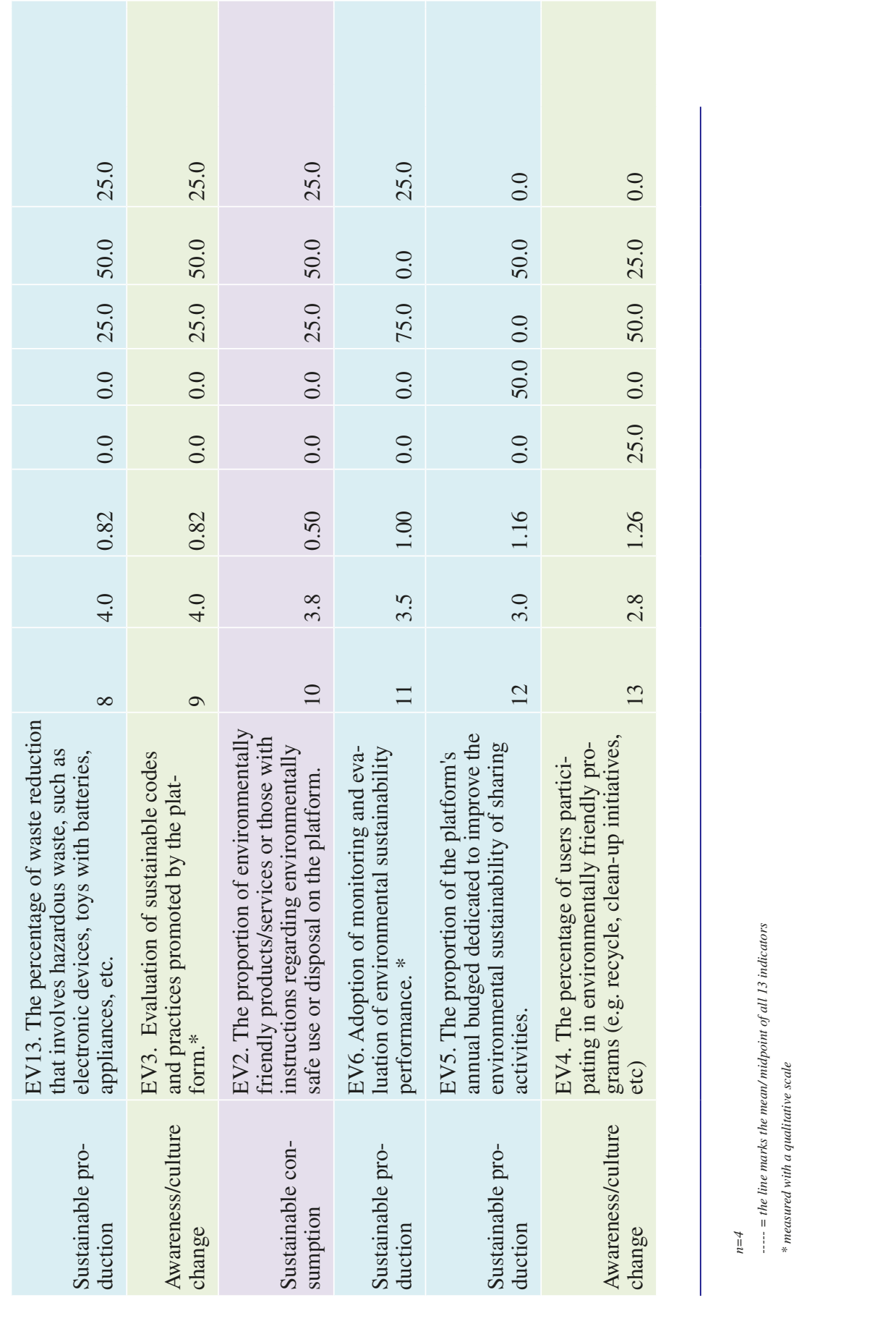

EMPIRIA. Revista de Metodología de Ciencias Sociales. N. 49 enero-abril, 2021, pp. 87-119. ISSN: 1139-5737, DOI/ empiria.49.2021.29233 


\section{RESULTS ANALYSIS}

The objective of this research was to develop a series of indicators that would provide a comprehensive and independent framework for monitoring the impact of collaborative consumption. The purpose of such a framework is to assist policy makers and public administrators in their efforts to develop policy and regulation. This framework serves also for conceptualising collaborative consumption impacts and improving further research, and it can be summarized in the following figure, composed of a nine-element sub-structure to the three general impact dimensions (figure 1).

\section{Figure 1. Collaborative consumption impact dimensions and sub-dimensions. Source: By authors.}

\begin{tabular}{|c|c|c|c|}
\hline & $\begin{array}{l}\text { Prosumer } \\
\text { empowerment }\end{array}$ & $\begin{array}{l}\text { Consumer } \\
\text { empowerment }\end{array}$ & $\begin{array}{l}\text { Economic } \\
\text { stimulation }\end{array}$ \\
\hline 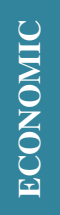 & $\begin{array}{l}\text { Empowerment of } \\
\text { 'prosumer' to generate } \\
\text { wealth (or other social } \\
\text { benefits) by taking } \\
\text { advantage of idle/ } \\
\text { excess capacity }\end{array}$ & $\begin{array}{l}\text { Empowerment of the } \\
\text { consumer through } \\
\text { pricing, choice and } \\
\text { access }\end{array}$ & $\begin{array}{l}\text { Macro level measures } \\
\text { of economic impact }\end{array}$ \\
\hline & $\begin{array}{l}\text { Community building/ } \\
\text { networking }\end{array}$ & $\begin{array}{l}\text { Social equality/ bridging } \\
\text { connections }\end{array}$ & $\begin{array}{l}\text { User empowerment } \\
\text { (trust systems } \\
\text { monitoring and control) }\end{array}$ \\
\hline $\begin{array}{l}\$ \\
\varnothing \\
8\end{array}$ & $\begin{array}{l}\text { The degree (or lack } \\
\text { of) and quality of } \\
\text { interaction between } \\
\text { users }\end{array}$ & $\begin{array}{l}\text { The degree (or lack } \\
\text { of) and quality of } \\
\text { interaction between } \\
\text { users from different } \\
\text { socio-cultural and } \\
\text { economic backgrounds }\end{array}$ & $\begin{array}{l}\text { Empowerment of } \\
\text { users to interact with } \\
\text { other users, normally } \\
\text { through technological } \\
\text { capabilities related to a) } \\
\text { trust/reputation and b) } \\
\text { control and monitoring }\end{array}$ \\
\hline \multirow[b]{2}{*}{ 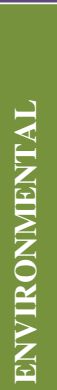 } & $\begin{array}{l}\text { Sustainable } \\
\text { consumption }\end{array}$ & $\begin{array}{l}\text { Sustainable } \\
\text { production }\end{array}$ & $\begin{array}{l}\text { Awareness/ } \\
\text { culture change }\end{array}$ \\
\hline & $\begin{array}{l}\text { Consumer actions that } \\
\text { affect environmental } \\
\text { sustainability through } \\
\text { changes in consumer } \\
\text { behaviour and } \\
\text { consumption patterns }\end{array}$ & $\begin{array}{l}\text { Development of } \\
\text { new sustainable } \\
\text { 'supply' chains, } \\
\text { through 'localisation' } \\
\text { of exchanges, } \\
\text { disintermediation, } \\
\text { sustainable transport } \\
\text { etc. }\end{array}$ & $\begin{array}{l}\text { Promotion of } \\
\text { sustainable values } \\
\text { and a culture of } \\
\text { environmental } \\
\text { awareness }\end{array}$ \\
\hline
\end{tabular}


The economic dimension contains thirteen indicators in three sub-dimensions, including: prosumer empowerment, consumer empowerment and economic stimulation. Notable was the way the experts helped to develop items that would conceptualise prosumer empowerment as separate from consumer empowerment. This implies the continuity of the structural barrier between providers and consumers, eroding the very idea of the "prosumer" as a concept. In addition, the providers to consumer ratio (EC10) is in the lower positions of the ranking, implying that economic experts do not even consider this to be a main feature of the collaborative consumption trend. In fact, this result weakens arguments for it to be associated with a new way of consumption. In contrast, most of the main indicators had to do with direct earnings and advantages: purchasing power, monetization, impact on local economy, money earned, money spent. These are mainly indicators related to the efficiency of the model, and not really with the development of new economic dynamics. In this sense, through their choices, the economic experts framed what can really be expected from this trend, which is not a paradigmatic change in consumption, but rather a more efficient system of economic stimulation. In this regard, the only two remarkable innovative characteristics are its prospects to improve local economies and the relevance of reputation regarding income, that is, how it is converted into a new currency. Finally, ranked lowest of all, there is the indicator of tax contribution in the country of operation. Given the ongoing controversy related to regulations and tax this is somewhat surprising. Taken as a whole, it is notable how the economic indicators focus heavily on the individual (prosumer or consumer) rather than systemic measures. In this respect, it would seem crucial that they be measured in conjunction with the social and environmental dimensions.

The social dimension was the most complex impact area, containing 21 indicators in three sub-dimensions. It is notable that the two highest ranked sub-dimensions, community building/networking and social equality/ bridging, reflect the experts' view that the impact of collaborative consumption on 'connections' between people and also between people of different societal cohorts is a critical area. As we noted in the literature review, developing connections is one of the main claims made by proponents of the collaborative economy, but the nature and quality of these relations have been called into question. Our own research suggests that technologically heavy distributed-network type platforms may account for a high proportion of connections, but that they are oriented toward 'managed' one-off transactions by individuals rather than being relationally focused (de Rivera et al., 2016). Using the suggested indicators, which measure local, non-monetary and alternative currency transactions, and widerparticipation, it should be possible to shed further light on the nature and quality of social transactions.

Closely associated, but with a lower overall importance rating, are a group of indicators designed to measure to what degree platforms technologically facilitate users' interactions through trust and reputation systems and monitoring and control procedures. Trust and reputation systems have been reported to be unreliable (Codagnone et al., 2016) and to reduce the quality of social connec- 
tions (Parigi \& State, 2014). From a relational perspective, it is important to measure these impacts at platform level and to further study how benefits are subsequently accrued at the economic level (in terms of prosumer and consumer empowerment) and how this may come into conflict with other social concerns.

Finally, there is the environmental dimension that caused us some difficulty in the final multipanel round. We have chosen to present the mean scores of the ranks by the four participating experts, which at first may seem overly restricted even for a Delphi. Undoubtedly, this is not ideal, but it should be taken into consideration that Round 3 indicators are merely the most advanced version of those developed in Rounds 1 and 2, where thirty-two and twenty-nine experts participated, respectively. Here, the three sub-dimensions are: sustainable consumption, sustainable production and awareness/cultural change.

In the sustainable consumption sub-dimension, the experts focus on environmental gains due to changes in consumption, such as waste reduction, re-use and curatorship/durability of product use. These first-order effects are the most commonly claimed benefits of collaborative consumption and it is necessary to measure them; however it should also be considered that there is a certain limitation in the indicators, as systemic wide waste and costs of maintaining a digital economy are not considered (Pargman et al, 2016; Kostakis, Roos \& Bauwens, 2016). In any case, such second-order effects are probably beyond the scope of this research. Furthermore, this sub-dimension has an important relationship to the prosumer and consumer empowerment sub-dimensions in terms of economic impact, as there may be considerable conflict between the impact of prosumers offering cost-competitive spare resources and consumers having greater economic power, ultimately leading to hyper-consumption with many secondary environmental costs. In this respect, the sustainable production sub-dimension focuses on geographic sustainability, transport efficiency, disintermediation and waste reduction and should also be considered in terms of its inter-relationship with economic impacts.

\section{CONCLUSION}

In March 2011, Time considered the sharing economy as one of the " 10 Ideas That Will Change the World" under the headline "Today's Smart Choice: Don't Own. Share" (Walsh, 2011). This publication became a "must" for first wave sectorial reports and early academic studies on the sharing economy and collaborative consumption (approximately 2010-2016), regardless of whether they were advocates or critical. However we do not remember any commentary directed at the subtitle of this already hackneyed publication, which reads as follows: "Our best shots for tackling our worst problems, from war and disease to unemployment and deficits".

A decade later, most of what was considered as the sharing or collaborative economy seems to be more part of the problem than the solution, as it is increasingly linked to job precariousness, over-consumption and gentrification. 
Over time, the term has been substituted by others, such as platform economy or platform capitalism, which emphasize the for-profit dynamics behind this so-called "socio-economic movement" (Botsman \& Rogers, 2010). In addition, criticisms have grown over the last decade, mainly focused on controversies about the accuracy of "sharing" or "collaborating" describing the nature of these platforms (Belk, Eckhardt \& Bardhi, 2019). In this context, the lack of independent research on their actual impact in society has maintained the debate on the theoretical and political level.

The proposal by four European consumer organizations--OCU (Spain), Test Achats (Belgium), Altroconsumo (Italy) and Deco Proteste (Portugal) - to carry out a broad research project measuring the impact of collaborative consumption platforms was a courageous move aimed at addressing these controversies (OCU, 2016). The underlying aim of this initiative was to empirically test the "collaborative consumption hypothesis", that is, the argument that these platforms will help to resolve economic, social and environmental issues. Thus, we were looking to tackle the impasse in the theoretical discussion by means of empirical research. In this regard, this is the first independent research project with such an aim, and the Delphi study presented here is at its core.

For the purpose of our research, we followed the canonical definition of collaborative consumption, but operationalized the concept as the practice of peer-to-peer exchange platforms that operate in several economic sectors. Our lead was seconded by subsequent research on the issue, such as the European Commission's "Exploratory Study of consumer issues in peer-to-peer platform markets" (2017), a key report for the development of legal regulation of these economies, which was directly inspired by the experience of the research commissions of the aforementioned European consumer organizations.

As we explained in the methodological section, the aim of the Delphi study was to develop an assessment tool to measure the economic, social and environmental impacts of these platforms. This would make it possible to calculate the aggregate impact of the overall trend, either validating or refuting the "collaborative consumption hypothesis". However, in doing so we had to account for the performance of each platform separately. This is highly relevant, because the main point of the collaborative consumption theory is that all peer-to-peer platforms are part of the same phenomenon or common trend. As a consequence, the mere intention of accounting for each platform's performance destroyed the illusion that community based, non-for-profit platforms would have similar impacts as multimillion dollar platforms funded by venture capital. Thus, the report published from this research was the first institutional research report to openly question the claims of collaborative consumption advocates, as can be inferred by its title: "Collaboration or business? Collaborative consumption: From value to users to a society with values" (OCU, 2016).

However, as we pointed out before, the application of the Triple Impact Assessment Questionnaire was not successfully completed. First, there was resistance to providing data, especially from the most profit oriented platforms, who were not willing to provide information that could benefit their potential 
competitors. Secondly, small organizations found it difficult to provide detailed data. Finally, the major issue was the wide range of activities that had to be evaluated with a single questionnaire. This was the result of the assumption that collaborative consumption platforms shared very similar or equivalent dynamics, which was empirically impracticable. To empirically account for this diversity, we conducted netnographic research that was included in the same project and has been discussed elsewhere (de Rivera et al., 2016). This also contributed to questioning and countering the most unrealistic claims of the advocates of the sharing and collaborative economy. Our subsequent work intensified this line of critical research, leading us to the conclusion that collaborative economy discourses were a complex marketing strategy on behalf of the major companies of the sector (de Rivera \& Gordo, in-print).

At the same time, theoretical debates on the phenomenon were mainly focused on the meaning of sharing and its incompatibility with profit driven markets. A considerable amount of literature on the topic is based on the original idea of a not-for-profit sharing economy that was later co-opted by corporations, while other scholars try to establish coherent definitions of what the sharing economy is (Frenken \& Schor, 2019). Indeed, there are several proposals to recapture the failed promises of the sharing economy by developing new organizational models based on shared platform ownership and democratic decision making (Schor, 2014; Orsi, 2014; Sholtz, 2014).

Following this trend, many have seen the potential of digital platforms to supersede capitalist values and dynamics, opening the way to more sustainable narratives for the sake of human survival (Schröder et al., 2019). Current conceptions of a circular economy and degrowth are increasingly being considered as two major prerequisites to operate within ecological planetary boundaries, especially in view of the challenge posed by a post-coronavirus economy (Boffey, 2020). In this regard, research such as that presented here provides a methodological and theoretical framework to develop tools to measure the impact of new digital economic models based on peer-to-peer platforms. The three-dimensional framework, with its nine sub-dimensions, offers a valuable starting point to understand how and in what areas online exchange platforms can contribute to positive social transformation.

\section{REFERENCES}

ACQUIER, A., DAUDIGEOS, T. \& PINKSE, J. (2017): "Promises and paradoxes of the sharing economy: An organizing framework", Technological Forecasting and Social Change, 125, pp. 1-10. https://doi.org/10.1016/j.techfore.2017.07.006

ALLEN, D., \& BERG, C. (2014): The sharing economy: How over-regulation could destroy an economic revolution. Melbourne: Institute of Public Affairs. Available at https://ipa.org.au/wp-content/uploads/archive/Sharing Economy December 2014. pdf [accessed: 27-05-2020]. 
ARROYO, L., MURILLO, D. \& VAL, E. (2017): Confiados y confiables. La fabricación de la confianza en la era digital, Barcelona, ESADE.

BELK, R. (2014): "You are what you can access: Sharing and collaborative consumption online", Journal of business research, 67 (8), pp. 1595-1600.

BELK, R., ECKHARDT, G. \& BARDHI, F. (2019): "Introduction: the paradox of the sharing economy", in Handbook of the Sharing Economy. Elgar Online Publishing, pp. 1-8. https://doi.org/10.4337/9781788110549

BENKLER. Y. (2004): "Sharing nicely: On shareable goods and the emergence of sharing as a modality of economic production", The Yale Law Journal, 114 (273), pp. 273-358. http://doi.org/10.2307/4135731

BOFFEY, D. (2020): “Amsterdam to embrace 'doughnut' model to mend post-coronavirus economy”, The Guardian, 8th April. Available at https://www.theguardian. com/world/2020/apr/08/amsterdam-doughnut-model-mend-post-coronavirus-economy [accessed: 27-05-2020].

BÖRJESSON-RIVERA, M., HÅKANSSON, C., SVENFELT, A. \& FINNVEDEN, G. (2014): "Including second order effects in environmental assessments of ICT", Environmental Modelling \& Software, 56, pp 105-115. http://doi.org/10.1016/j.envsoft.2014.02.005

BOTSMAN, R. \& ROGERS, R. (2010): What's mine is yours: The Rise of Collaborative Consumption, New York, Harper Collins.

BOTSMAN, R. (2017): Who Can You Trust?: How Technology Brought Us Together - and Why It Could Drive Us Apart, New York, Penguin Books.

BULCHAND, J. \& MELIAN, S. (2018): La revolución de la economía colaborativa, Madrid, LID Editorial.

CODAGNONE, C., BIAGI, F. \& ADABIE, F. (2016): The passions and the interests: Unpacking the 'Sharing Economy'. Institute for Prospective Technological Studies, JRC Science for Policy Report. Available at https://publications.jrc.ec.europa. eu/repository/bitstream/JRC101279/jrc101279.pdf [accessed: 27-05-2020].

COHEN, M. J. (2016): "The (Mostly) Empty Promise of the Sharing Economy", in The Future of Consumer Society: Prospects for Sustainability in the New Economy. Oxford University Press. http://doi.org/10.1093/acprof:o so/9780198768555.003.0003

COX, M. \& SLEE, T. (2016): "How Airbnb's data hid the facts in New York City", Inside Airbnb. Available at http://insideairbnb.com/reports/how-airbnbs-data-hid-thefacts-in-new-york-city.pdf [accessed: 27-05-2020].

COYLE, D. (2016): The Sharing Economy in the UK. Available at $\underline{\text { http://www. }}$ sharingeconomyuk.com/perch/resources/210116thesharingeconomyintheuktpdc. docx1111.docx-2.pdf [accessed: 27-05-2020].

DeGROEN, W.P., \& MASELLI, I. (2016): The Impact of the Collaborative Economy on the Labour Market, Brussels, Centre for European Policy Studies.

DEMAILLY, D. \& NOVEL, A.S. (2014): The sharing economy: make it sustainable. Iddri, 03 (July). Available at https://www.iddri.org/sites/default/files/import/publications/st0314_dd-asn_sharing-economy.pdf [accessed: 27-05-2020].

DEMARY, V. (2015): The platformization of digital markets: Comments on the public consultation of the European Commission on the regulatory environment for platforms, online intermediaries, data and cloud computing and the collaborative economy, IW policy paper, No. 39/2015. Available at https://www.econstor.eu/bitstream/10419/126091/1/845730703.pdf [accessed: 27-05-2020]. 
de RIVERA, J., GORDO LÓPEZ, Á. \& CASSIDY, P. (2016): “A netnographic study of P2P collaborative consumption platforms' user interface and design”, Environmental Innovation and Societal Transitions, 23, pp. 11-27. http://dx.doi.org/10.1016/j. eist.2016.09.003

de RIVERA, J. (2019): Sociología de las instituciones digitales. El estudio de caso de la "economía colaborativa. Tesis doctoral, Universidad Complutense de Madrid.

de RIVERA, J. \& GORDO LÓPEZ, Á. (in-print): "La oleada de la economía colaborativa y el nuevo utilitarismo digital. Un análisis del trabajo fundacional de Bostman y Rogers (2010)", in Estudios sociales sobre el consumo, Madrid, Colección Academia, CIS.

DILLAHUNT, T. R. \& MALONE, A.R. (2015): "The promise of the sharing economy among disadvantaged communities", in Proceedings of the 33rd Annual ACM Conference on Human Factors in Computing Systems, pp. 2285-2294. Available at https://dl.acm.org/doi/pdf/10.1145/2702123.2702189 [accessed: 27-05-2020].

DOGRU, T., HANKS, L., OZDEMIR, O., KIZILDAG, M., AMPOUNTOLAS, A. \& DEMIRER, I. (2020): "Does Airbnb Have a Homogenous Impact? Examining Airbnb's Effect on Hotels With Different Organizational Structures", International Journal of Hospitality Management, 86, 102451, pp. 1-10. https://doi.org/10.1016/j. ijhm.2020.102451

DREYER, B., LÜDEKE-FREUND, F., HAMANN, R. \& FACCER, K. (2017): “Upsides and downsides of the sharing economy: Collaborative consumption business models' stakeholder value impacts and their relationship to context", Technological Forecasting and Social Change, 125, pp. 87-104. https://doi.org/10.1016/j.techfore.2017.03.036

EDELMAN, B. \& LUCA, M. (2014): Digital Discrimination: The Case of Airbnb.com. Harvard Business School. Working Paper No. 14-054. Available at http://www. west-info.eu/files/airbnb research.pdf [accessed: 27-05-2020].

EGLASH, R. (2016): "Of Marx and Makers: An historical perspective on generative Justice", Teknokultura, 13(1), pp. 245-269. http://dx.doi.org/10.5209/rev TK.2016. v13.n1.52096

EUROPEAN COMMISSION (2016): Synopsis report on the public consultation on the regulatory environment for platforms, online intermediaries and the collaborative economy. Brussels. Available at https://ec.europa.eu/digital-single-market/en/news/ full-report-results-public-consultation-regulatory-environment-platforms-online-intermediaries [accessed: 27-05-2020].

EUROPEAN COMMISSION (2017): Exploratory study of consumer issues in online peer-to-peer platform markets. Final report. Brussels. Available at: https://ec.europa. eu/newsroom/document.cfm?doc id=45245 [accessed: 27-05-2020].

EUROPEAN PARLIAMENT (2017): The Social Protection of Workers in the Platform Economy. Directorate-General for Internal Policies. Brussels. Available at https:// www.europarl.europa.eu/RegData/etudes/STUD/2017/614184/IPOL STU(2017)614184 EN.pdf [accessed: 27-05-2020].

FERNÁNDEZ-MACÍAS, E. (2017): “Automation, digitisation and platforms: implications for work and employment", Concept Paper. Eurofound: European Foundation for the Improvement of Living and Working Conditions. Available at https:// www.eurofound.europa.eu/sites/default/files/wpef17035.pdf [accessed: 27-052020]. 
FERNÁNDEZ-TRUJILLO MOARES, F. (2020): "Precariedad e inestabilidad: contradicciones en el trabajo en las plataformas de reparto de comida", Teknokultura, 17(1), pp. 35-40. https://doi.org/10.5209/tekn.65189

FRENKEN, K. (2017): "Political economies and environmental futures for the sharing economy", Philosophical Transactions of the Royal Society A: Mathematical, Physical and Engineering Sciences, 375 (2095), pp. 1-15. https://doi.org/10.1098/ rsta.2016.0367

FRENKEN, K. \& SCHOR, J. (2019): "Putting the sharing economy into perspective", in A Research Agenda for Sustainable Consumption Governance, Edward Elgar Publishing, pp. 121-135.

GIL, J. (2018): “¿Qué son las economías colaborativas?”, Papeles de relaciones ecosociales y cambio global, 141, pp. 47-60.

GORDO LÓPEZ, Á., de RIVERA, J. \& CASSIDY, P. (2017): «La economía colaborativa y sus impactos sociales en la era del capitalismo digital», in Ciberpolítica: gobierno abierto, redes, deliberación, democracia, Madrid, INAP, pp. 189-208.

HEINRICHS, H. (2013): "Sharing economy: A potential new pathway to sustainability", GAIA: Ecological Perspectives for Science \& Society, 22(4), pp. 228-231. https:// doi.org/10.14512/gaia.22.4.5

HOOK, L. (2017): "How Uber and Airbnb changed the rules", Financial Times, February $17^{\text {th }}$. Available at: https://www.ft.com/content/36096064-e48e-11e6-9645c9357a75844a [accessed: 13-06-2020]

HUWS, U., \& JOYCE, S. (2016): Crowd Work in Europe. University of Hertfordshire, Uni-Europa Global Union. Available at https://euagenda.eu/upload/publications/ untitled-88617-ea.pdf [accessed: 27-05-2020].

ILO. INTERNATIONAL LABOUR OFFICE (2018): Digital labour platforms and the future of work: Towards decent work in the online world. Geneva. Available at https://www.ilo.org/wcmsp5/groups/public/---dgreports/---dcomm/---publ/documents/publication/wcms 645337.pdf [accessed: 27-05-2020].

KEENEY, S., HASSON, F. \& MCKENNA, H. (2006): "Consulting the oracle: Ten lessons form using the Delphi technique in nursing research", Journal of Advanced Nursing, 53(2), pp. 205-212. http://doi.org/10.1111/j.1365-2648.2006.03716.x

KEENEY, S., HASSON, F. \& MCKENNA, H. (2011): The Delphi technique in nursing and health research, New Jersey, Wiley-Blackwell.

KOSTAKIS, V., ROOS, A. \& BAUWENS, M. (2016): "Towards a political ecology of the digital economy: Socio-environmental implications of two competing value models", Environmental Innovation and Societal Transitions, 18, pp. 82-100. http://doi. org/10.1016/j.eist.2015.08.002

LAURELL, C. \& SANDSTRÖM, C. (2017): "The sharing economy in social media: Analyzing tensions between market and non-market logics", Technological Forecasting and Social Change, 125, pp. 58-65. https://doi.org/10.1016/j.techfore.2017.05.038

LINSTONE, H. A. \& TUROFF, M. (2002): The Delphi Method - Techniques and applications, Boston MA, Addison-Wesley.

MAIR, J. \& REISCHAUER, G. (2017): "Upsides and downsides of the sharing economy: Collaborative consumption business models' stakeholder value impacts and their relationship to context", Technological Forecasting and Social Change, 125, pp. 87-104. https://doi.org/10.1016/j.techfore.2017.03.036 
MARTIN, C.J. (2016): “The sharing economy: A pathway to sustainability or a nightmarish form of neoliberal capitalism?" Ecological Economics, 121, pp. 149-159. http://doi.org/10.1016/j.ecolecon.2015.11.027

MARTÍNEZ DÍEZ, P. (2019): Categorización y efectos del consumo colaborativo sobre la economía. Trabajo Fin de Grado, Universidad de Valladolid.

MOROZOV, E. (2019): “Capitalism's New Clothes”, The Baffler, February, 4, 2019. Available at https://thebaffler.com/latest/capitalisms-new-clothes-morozov [accessed: 27-05-2020].

MURILLO, D., BUCKLAND, H. \& VAL, E. (2017): "When the sharing economy becomes neoliberalism on steroids: Unravelling the controversies", Technological Forecasting and Social Change, 125, pp. 66-76. https://doi.org/10.1016/j.techfore.2017.05.024

OCU. ORGANIZACIÓN DE CONSUMUIDORES Y USUARIOS (2016): Collaboration or Business? Collaborative consumption: From value for users to a society with values. OCU, Altoconsumo, Deco Proteste. Test-Achats. Available at https:// www.ocu.org/organizacion/ /media/lobbyandpressocu/images/que-hacemos/nuestras-acciones/2016/informe $\% 20$ ocu $\% 20$ economia $\% 20$ colaborativa/informe $\% 20$ ocu\%20consumo\%20colaborativo/collaboration \%20or\%20business \%20cc\%20 p2p\%202016.pdf [accessed: 27-05-2020].

OECD (2016): Working party on measurement and analysis of the digital economy: New forms of work in the digital economy. Directorate for Science, Technology and Innovation. Committee on Digital Policy. Available at http://www.oecd.org/ officialdocuments/publicdisplaydocumentpdf/?cote=DSTI/ICCP/IIS(2015)7/ FINAL\&docLanguage $=$ En [accessed: 27-05-2020].

OKOLI, C. \& PAWLOWSKI, S.D. (2004): "The Delphi method as a research tool: An example, design considerations and applications", Information \& Management, 42(1), pp. 15-29. https://doi.org/10.1016/j.im.2003.11.002

ORSI, J. (2014). The Next Sharing Economy. [Video]. Available at https://www. youtube.com/watch?v=xpg4PjGtbu0 [accessed: 27-05-2020].

OUISHARE (2015): About us. http://ouishare.net/en/about [accessed 01-11-2015]

PARGMAN, D., ERIKSSON, E. \& FRIDAY, A. (2016): "Limits to the sharing economy", in Proceedings of the Second Workshop on Computing within Limits. ACM. http://doi.org/10.1145/2926676.2926683

PARGUEL, B., LUNARDO, R. \& BENOIT-MOREAU, F. (2017): "Sustainability of the sharing economy in question: When second-hand peer-to-peer platforms stimulate indulgent consumption", Technological Forecasting and Social Change, 125, pp. 48-57. https://doi.org/10.1016/j.techfore.2017.03.029

PARIGI, P. \& STATE, B. (2014): "Disenchanting the world: The impact of technology on relationships", in Social Informatics. Lecture Notes in Computer Science, vol 8851, Switzerland, Springer International Publishing, pp. 166-182.

RANI, U. \& FURRER, M. (2019): "On-demand digital economy: Can experience ensure work and income security for microtask workers?" Jahrbücher für Nationalökonomie und Statistik, 239(3), pp. 565-597.

RAWORTH, K. (2017): Doughnut economics: seven ways to think like a 21st-century economist, Vermont, Chelsea Green Publishing.

RICHARDSON, L. (2015): "Performing the sharing economy", Geoforum, 67, pp. 121-129. http://doi.org/10.1016/j.geoforum.2015.11.004

RISO, S. (2020): The pandora's box of the platform economy. Eurofound: European Foundation for the Improvement of Living and Working Conditions. Available at 
https://www.eurofound.europa.eu/publications/blog/the-pandoras-box-of-the-platform-economy [accessed 27-05-2020].

ROGERS, B. (2016): Employment Rights in the Platform Economy: Getting Back to Basics. Harvard Law y Policy Review, 10. Temple University Legal Studies Research Paper No. 2015-33. http://dx.doi.org/10.2139/ssrn.2641305

ROWE, G. \& WRIGHT, G. (2001): "Expert Opinions in Forecasting: The Role of the Delphi Technique", in Principles of Forecasting: A Handbook for Researchers and Practitioners, Boston MA, Springer, pp. 125-144. http://doi.org/10.1007/978-0-30647630-3区

SCHMIDT, R., LYYTINEN, K., KEIL, M. \& CULE, P. (2001): "Identifying software project risks: An international Delphi study", Journal of Management Information Systems, 17(4), pp. 5-36. http://doi.org/doi:10.1080/07421222.2001.11045662

SCHMIDT, F.A. (2017): Digital labour markets in the platform economy: Mapping the political challenges of crowd work and gig work, Bonn, Friedrich-Ebert-Stiftung.

SCHOLZ, T. (2014): Platform Cooperativism vs. the Sharing Economy, 5 December 2014. Available at: https://medium.com/@trebors/platform-cooperativism-vs-thesharingeconomy-2ea737f1b5ad\#.p39j64v5d [accessed 27-05-2020].

SCHOR, J. (2014): "Debating the Sharing Economy." The Great Transition Initiative. Available at http://www.greattransition.org/publication/debating-the-sharing-economy [accessed 27-05-2020].

SCHOR, J. B., FITZMAURICE, C., CARFAGNA, L.B. \& ATTWOOD-CHARLES, W. (2016): "Paradoxes of openness and distinction in the sharing economy", Poetics, 54, pp. 66-81. http://doi.org/10.1016/j.poetic.2015.11.001

SCHRÖDER, P., BENGTSSON, M., COHEN, M., DEWICK, P., HOFFSTETTER, J. \& SARKIS, J. (2019): "Degrowth within-Aligning circular economy and strong sustainability narratives", Resources, Conservation and Recycling, 146, pp. 190-191. https://doi.org/10.1016/j.resconrec.2019.03.038

SKOK, W. \& BAKER, S. (2018): "Evaluating the impact of Uber on London's taxi service: A critical review of the literature", Knowledge and Process Management. The Journal of Corporate Transformation, 26(1), pp. 3-9.

SRNICEK, N. (2016): Platform Capitalism, New Jersey, Wiley-Blackwell.

STOKES, K., CLARENCE, E., ANDERSON, L. \& RINNE, A. (2014): Making sense of the Uk collaborative economy, Nesta, Collaborative Lab. Available at https:// www.nesta.org.uk/report/making-sense-of-the-uk-collaborative-economy/ [accessed 27-05-2020].

SUNDARARAJAN, A. (2016): The sharing economy: The end of employment and the rise of crowd-based capitalism, Boston MA, MIT Press.

TEUBNER, T., HAWLITSCHEK, F. \& DANN, D. (2017): "Price determinants on AirBnB: How reputation pays off in the sharing economy", Journal of Self-Governance \& Management Economics, 5(4), pp. 53-80. http://doi.org/10.22381/JSME5420173

TNS (2016): Flash Eurobarometer 438 Briefing note - The use of collaborative platforms. TNS Political and Social / European Commission. Available at https:// ec.europa.eu/COMMFrontOffice/publicopinion/index.cfm/ResultDoc/download/ DocumentKy/72886 [accessed 27-05-2020].

TORREGROSSA, M. (2013): The Sharing Economy: Training toolkit based on strength, weaknesses, opportunities and threats (SWOT). Available at http://www.slideshare. net/speed101/the-rise-of-the-sharing-economy [accessed 27-05-2020].

VALLAS, S.P. (2019): "Platform Capitalism: What is at Stake for Workers?" New Labor Forum, 28(1), pp. 48-59. https://doi.org/10.1177\%2F1095796018817059 
VERBOVEN, H. \& VANHERCK, L. (2016): “The sustainability paradox of the sharing economy", uwf, UmweltWirtschaftsForum, 24(4), pp. 303-314. https://doi. org/10.1007/s00550-016-0410-y

WAGNER, T., KUHNDT, M., LAGOMARSINO, J. \& MATTAR, H. (2015): Listening to sharing economy initiatives. Report on a Global Survey. Collaborating Centre on Sustainable Consumption and Production (CSCP). Available at http://www.scpcentre.org/wp-content/uploads/2016/05/Listening to Sharing Economy Initiatives. pdf [accessed 27-05-2020].

WALSH, B. (2011): “Today’s Smart Choice: Don’t Own. Share”, Time Magazine, March 17th. Available at http://content.time.com/time/specials/packages/article/0,28804,2059521 2059717,00.html [accessed 27-05-2020].

ZERVAS, G., PROSERPIO, D. \& BYERS, J. (2017): "The rise of the sharing economy: Estimating the impact of Airbnb on the hotel industry", Journal of Marketing Research, 54(5), pp. 687-705. https://doi.org/10.1509\%2Fjmr.15.0204 
